\title{
Growth and longevity in acanthurid fishes; an analysis of otolith increments
}

\author{
J. H. Choat*, L. M. Axe \\ Department of Marine Biology, James Cook University, Townsville, Queensland 4811, Australia
}

\begin{abstract}
Increments in the sagittal otoliths from 10 species of acanthurid fishes from eastern Australian coral reefs were used to estimate age. The species included representatives of 5 genera: Acanthurus lineatus, A. olivaceus, Ctenochaetus striatus, Zebrasoma scopas, Naso brevirostris, N. hexacanthus, N. tuberosus, N. unicornis, N. vlamingii, and Prionurus maculatus. Systematic increments consisting of alternating opaque and translucent bands were observed in the sectioned sagittae of all 10 species. Regression of numbers of increments on sagittal weights revealed consistent linear relationships between these variables in all species examined indicating continuous growth in sagittal thickness over the life span. For A. lineatus, A. olivaceus, $C$. striatus and $Z$. scopas recapture of specimens injected with tetracycline confirmed an annual pattern in increment formation with an opaque band being formed in early austral summer. Size at age plots revealed consistent growth patterns and life spans. All species examined had life spans of 30 to $45 \mathrm{yr}$ in which rapid initial growth over 3 to 4 yr was followed by extended periods of asymptotic growth. In these species up to $80 \%$ of linear growth was accomplished in the initial $15 \%$ of the life span. Analysis of otoliths from the 5 species of Naso and $P$. maculatus, while not validated, revealed similar increment distributions within the sagitta, similar relationships between increment number and otolith weight, and simllar size at age plots. Acanthurid fishes from eastern Australia appear to have consistent patterns of growth and longevity despite marked differences in asymptotic size, diet and mode of life.
\end{abstract}

KEY WORDS: Acanthurid fishes · Growth · Longevity · Otolith increments - Validation

\section{INTRODUCTION}

Fishes of the family Acanthuridae are abundant and defining members of coral reef fish faunas (Russ 1984a, b, Choat \& Bellwood 1991, Williams 1991). Although usually classified as herbivores, these fishes exhibit a variety of feeding patterns including detritus feeding, macroalgal browsing and selective feeding on large gelatinous zooplankton (Jones 1968, Winterbottom \& McLennan 1993, Clements \& Choat 1995). Five genera, Naso, Zebrasoma, Paracanthurus, Acanthurus and Ctenochaetus, are present on Indo-Pacific reefs with species of Acanthurus and Ctenochaetus being dominant members of some faunas (Choat \& Bellwood 1985, Williams 1991, McClanahan 1994). A sixth genus, Prionurus, appears to be restricted to subtropical reef habitats (Choat 1991).

\footnotetext{
•E-mail: ann.sharp@jcu.edu.au
}

The phylogenetic relationships and feeding patterns amongst these genera have been analysed by Winterbottom \& McLennan (1993). There are a wide range of dietary patterns exhibited with macroscopic algal browsing being the plesiomorphic condition. The basal species within Naso and Acanthurus appear to be herbivorous with carnivory a derived condition. Species within the Acanthuridae also display a wide range of maximum sizes ranging from $180 \mathrm{~mm}$ standard length (SL) in members of the genus Ctenochaetus to $860 \mathrm{~mm}$ SL in some species of Naso (Randall et al. 1990).

The purpose of this study was to examine size at age, growth rates and life spans in a suite of Indo-Pacific acanthurid species. The availability of a phylogenetic classification provides an appropriate framework for the comparison of growth rates and longevities across a range of feeding types, size ranges and taxonomic identities in this ecologically diverse group of coral reef fishes. 
The increasing documentation of the annual nature of sagittal. increments (Manooch \& Drennon 1987. Fowler 1990, 1995, Ferreira \& Russ 1992, 1994, Lou 1992, Doherty \& Fowler 1994) provides a basis for estimating growth rates and life spans in coral reef fishes in general and acanthurids in particular (Hart \& Russ in press). Our study provides further support for the identity of annual sagittal increments in members of the acanthurid genera Acanthurus, Ctenochaetus and Zebrasoma and for their use as demographic tools.

Estimates of age structure and growth rates of tropical demersal fishes are biased toward particular taxa, particularly lutjanids, haemulids, sparids and serranids (Buesa 1987, Fowler 1995). These large carnivores are relatively easy to sample for tagging purposes, and, as traditional targets for coral reef fisheries (Alcala \& Russ 1990), are likely to provide good returns to recapture schemes (Munro \& Williams 1985). However, they represent only a limited range of the taxa that make up reef fish assemblages. Emphasis on these groups will produce a selective picture of growth and life history patterns in coral reef fishes

Other taxa such as acanthurids, scarids, siganids and labrids are both highly characteristic of coral reefs and increasingly targeted in localized reef-based fisheries (Russ 1991, DeMartini 1993, Wright 1993). Information on their demography is relatively limited, partly due to the difficulty in sampling and establishing markrecapture programs, especially in the larger and more active members of the Acanthuridae and Scaridae. Consequently, for many large and previously abundant groups of reef fishes we lack even rudimentary information on growth rates and life spans.

This problem is illustrated by members of the genus Naso. Nasiid acanthurids are difficult to sample and collect, especially in an unharmed state suitable for tagging. Although they may be locally abundant and important in some coral reef fisheries, there is little chance that they will be included in conventional fisheries programs

An opportunity to sample numbers of Naso species was provided by a related study on acanthurid feeding and digestion (Clements \& Choat 1995). This provided substantial numbers of Naso distributed amongst 5 species for the analysis of sagittal increments. These data are presented for comparative purposes. As we have not unambiguously established the annual nature of these increments, estimates of growth and longevity in Naso are presented as hypotheses for further examination.

\section{MATERIAL AND METHODS}

Study species and localities. Four acanthurid species, Acanthurus olivaceus, Acanthurus lineatus, Zebrasoma scopas and Ctenochaetus striatus were used for estimates of growth and longevity based on validated sagittal annuli. These species covered a range of feeding types (Jones 1968, Robertson et al. 1979, Robertson \& Gaines 1986, Clements \& Choat 1995) including sand and sediment grazing (A. olivaceus), algal grazing (A. lineatus), algal browsing ( $Z$. scopas) and detrjtal feeding (C. striatus). The majority of individuals of these species were collected from reefs surrounding Lizard Island $\left(14^{\circ} 40^{\prime} \mathrm{S}, 145^{\circ} 28^{\circ} \mathrm{E}\right)$ with a small number being collected from adjacent mid-shelf reefs.

In addition, 5 species of the genus Naso ( $N$. brevirostris, $N$. hexacanthus, $N$. tuberosus, $N$. unicornis and $N$. vlamingii) with a dietary range spanning algal browsing, planktivory and coprophagy (Robertson 1982, Clements \& Choat 1995) were examined for patterms of sagittal increments. Most specimens of $\mathrm{Naso}$ spp. were collected on fronts and passes of the Outer Barrier Reefs (Hicks, Day \& No Name Reefs) 15 to $25 \mathrm{~km}$ northeast of Lizard. Island (general collection data are shown in Table 1). Most acanthurids were collected by spearing or by $1.5 \times 30 \mathrm{~m}$ drive nets on reef crests and slopes. Small individuals were collected using fine-mesh $(5 \mathrm{~mm})$ drive nets.

A small number of acanthurids including members of the genus Naso and Prionurus maculatus were collected from Middleton Reef $\left(29^{\circ} 28^{\prime} \mathrm{S}, 159^{\circ} 7^{\prime} \mathrm{E}\right)$ the southern most true coral reef. The sampled individuals represented acanthurids subject to stronger environmental signals than those on northern reefs and the sagittae were retained for comparison with Lizard Island material.

Tagging and otolith processing. The main tagging program was carried out at Lizard Island in November 1991 and February 1992, although a small number of acanthurids were tagged at Lizard Island in 1989. In addition, a supplementary tagging program for Naso brevirostris was carried out at Hicks Reef in November 1993. Fish were collected for tagging by the use of $1.5 \times$ $30 \mathrm{~m}$ drive nets (50 $\mathrm{mm}$ mesh) measured to the nearest $\mathrm{mm}$ for standard length (SL) and fork length (FL) and tagged immediately on site. Individually numbered T-bar anchor tags were inserted between the dorsal pterygiophores. Each fish was injected in the visceral cavity with a solution of oxytetracycline and saline with a dosage of $50 \mathrm{mg} \mathrm{kg}^{-1}$ body weight of fish (McFarlane \& Beamish 1987) with the dosage converted to length of fish based on length-weight relationships (see Table 2). Recaptures were made by spearing at tagging sites after periods at liberty ranging from 11.5 to $48 \mathrm{mo}$.

It was not possible to obtain tagging records for $0+$ fish. To check the position of the first annulus, newly settled fish were maintained in an outdoor aquarium system for periods of greater than $365 \mathrm{~d}$. Fish of known 
size and estimated age at capture were examined for annulus formation after periods of 12 to 24 mo.

On capture, fish were placed on ice and processed in the laboratory on the same day. Length (SL and FL) measurements to the nearest $\mathrm{mm}$ and total weight to the nearest gram were made by measuring board and an electronic balance. For each individual, gutted weight and weight of the alimentary tract, liver and gonad were also obtained. Both sagittae and lapillae were removed, cleaned in distilled water and stored dry after washing with ethanol

Only sagittae were used for aging purposes. One of each pair was weighed to $0.1 \mathrm{mg}$. This was embedded in epoxy resin, sectioned transversely at 300 to $500 \mu \mathrm{m}$ through the core using a low speed Buehler isomet saw and ground using 600,800 and 1200 grit abrasive paper. Otolith sections were mounted on a glass slide with thermoplastic glue (Crystallbond) and polished using 0.3 micron alpha alumina powder and a polishing cloth

Sectioned otoliths were examined under both high power and dissecting microscopes using transmitted light. Each otolith was examined and read independently at 3 different times at a minimum of $3 \mathrm{wk}$ apart for incremental bands representing annuli. Counts of increments were taken at the positions shown in Fig. 1

Precision of age estimates was then calculated using the Index Average Percent Error of Beamish \& Fournier (1981). For species of the genus Naso counts were made on samples which included small individuals $(<4$ increments) and larger individuals with $>4$ increments. Accuracy of sagittal readings was assessed using the position of tetracycline bands in the otolith relative to the positions of opaque increment structures and the sagittal margin.

Validated length at age plots were fitted to a regression model. Regressions of the form $\log y=\log a+$ $b \log x$ gave the best fit to the data. The main purpose of this study was to describe the observed patters. No attempt has been made at this stage to fit growth models with particular assumptions to the data. For species of Naso the $x$-axis was identified only as sagittal increments (number of bands). The relationship between otolith weight and annulus number was examined by least-squares regression analysis with sagittal weight as the independent variable.

The numbers, size ranges, tagging and recapture data for each of the 10 species sampled for this study are provided in Table 1.

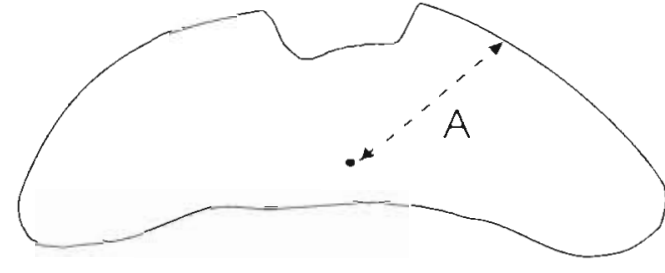

Fig. 1. Sagittal otolith in sectional view. Line A identifjes the track along which counts of increments were made

\section{RESULTS}

\section{Length-weight relationships}

Length-weight relationships in the 10 species examined displayed predictable values $(b$ ranged from 2.50 to 3.06 ) when the equation $W=a L^{b}$, where $L$ was standard length, was fitted (Table 2). The $\mathrm{r}^{2}$ values ranged from 0.963 to 0.999

\section{Otoliths and validation}

When viewed in transverse section, sagittae of Acanthurus lineatus, A. olivaceus, Zebrasoma scopas and Ctenochaetus striatus showed well defined systematic increments or banding patterns with opaque bands alternating with translucent bands (Fig. 2). Compared with other reef fishes such as scarids (Lou 1992) and serranids (Ferreira \& Russ 1994), opaque bands were more numerous and tightly spaced, especially near the outer margins of the sagitta. Although some difficulty was encountered in identifying structures near the margins, total counts of opaque bands could be made in all species examined. The difficulties in obtaining consistent preparations and measurements at the margin made attempts to monitor mar-

Table 1. Number and size ranges of 10 species of acanthurd collected for otolith processing and tagging program

\begin{tabular}{|c|c|c|c|c|c|c|}
\hline Species & $\begin{array}{l}\text { No. } \\
\text { fish }\end{array}$ & $\begin{array}{l}\text { Size } \\
\text { range } \\
(\mathrm{mm})\end{array}$ & $\begin{array}{l}\text { No. } \\
\text { tagged }\end{array}$ & $\begin{array}{l}\text { Size } \\
\text { range } \\
(\mathrm{mm})\end{array}$ & $\begin{array}{l}\text { Total no. } \\
\text { of recap- } \\
\text { tures }\end{array}$ & $\begin{array}{l}\text { No otoliths } \\
\text { with tetra- } \\
\text { cycline band }\end{array}$ \\
\hline Acanthurus lineatus & 94 & $76-206$ & 45 & $169-195$ & 6 & 4 \\
\hline A. olivaceus & 177 & $26-248$ & 21 & $147-242$ & 4 & 3 \\
\hline Ctenochaetus striatus & 176 & $28-197$ & 143 & $115-186$ & 27 & 22 \\
\hline Zebrasoma scopas & 70 & $24-157$ & 47 & $91-144$ & 18 & 10 \\
\hline Naso brevirostris & 173 & $47-330$ & 186 & $117-340$ & 2 & 0 \\
\hline N. hexacanthus & 61 & $57-534$ & 0 & - & - & - \\
\hline N. tuberosus & 85 & $28-457$ & 1 & 216 & 0 & 0 \\
\hline N. unicornis & 56 & $50-457$ & 0 & - & - & - \\
\hline N. vlamingii & 92 & $53-387$ & 6 & $153-190$ & 0 & 0 \\
\hline Prionurus maculatus & 16 & $252-566$ & 0 & - & - & - \\
\hline
\end{tabular}


Table 2. Length-weight relationships of 10 species of acanthurid fishes used in this study. For each species estimates of the parameters $a$ and $b$ for the relationshıp $W=a L^{b}$, coefficient of determination $\left(r^{2}\right)$, and the sample size $(n)$ are provided. Length is standard length $(\mathrm{mm})$

\begin{tabular}{|lcccrc|}
\hline Species & $a \times 10^{-5}$ & $b$ & $\mathrm{r}^{2}$ & $\mathrm{n}$ & Size range (mm! \\
\hline Acanthurus lineatus & 22.19 & 2.691 & 0.963 & 94 & $76-206$ \\
A. olivaceus & 3.385 & 3.055 & 0.998 & 177 & $26-248$ \\
Ctenochaetus striatus & 3.517 & 3.066 & 0.993 & 176 & $28-197$ \\
Zebrasoma scopas & 6.302 & 2.948 & 0.994 & 70 & $24-157$ \\
Naso brevirostris & 10.88 & 2.743 & 0.994 & 173 & $47-330$ \\
N. hexacanthus & 5.94 & 2.854 & 0.998 & 61 & $57-534$ \\
N. tuberosus & 9.064 & 2.806 & 0.999 & 85 & $28-457$ \\
N. unicornis & 8.495 & 2.843 & 0.997 & 56 & $50-457$ \\
N. vlamingii & 7.533 & 2.843 & 0.993 & 92 & $53-387$ \\
Prionurus maculatus & 62.0 & 2.504 & 0.989 & 15 & $207-447$ \\
\hline
\end{tabular}

ginal increment patterns (Manooch \& Drennon 1987

Lou 1992) unreliable.

Independent counts of bands were used to estimate precision, expressed as the average percent error (Beamish \& Fournier 1981). For Acanthurus lineatus, A. olivaceus, Ctenochaetus striatus and Zebrasoma scopas precision of counts varied from 5.3 to $5.9 \%$ (Table 3). As the number of increments within each otolith was relatively large, these results suggest an acceptable level of precision in counts of sagittae made independently at different times. For species of the genus Naso, precision was relatively low when sagittae with less than 4 increments were counted (Table 3). This indicates that the position and clarity of the initial increments in this genus are variable and special care should be taken in determining their position.

The relationship between number of opaque bands (expressed as age) and sagittal weight was examined by fitting least-squares regressions to the data (Fig. 3). For all species there was a significant positive relationship between fish age and otolith weight, although the form of the relationship varied amongst the species. Our interpretation is that otoliths show continuous linear or curvi-linear growth increase in weight over the life span of the fish.

A total of 263 individuals of the 4 species were tagged. The great majority of these were adult fishes (Table 1). Fifty-five tagged fish were recovered after
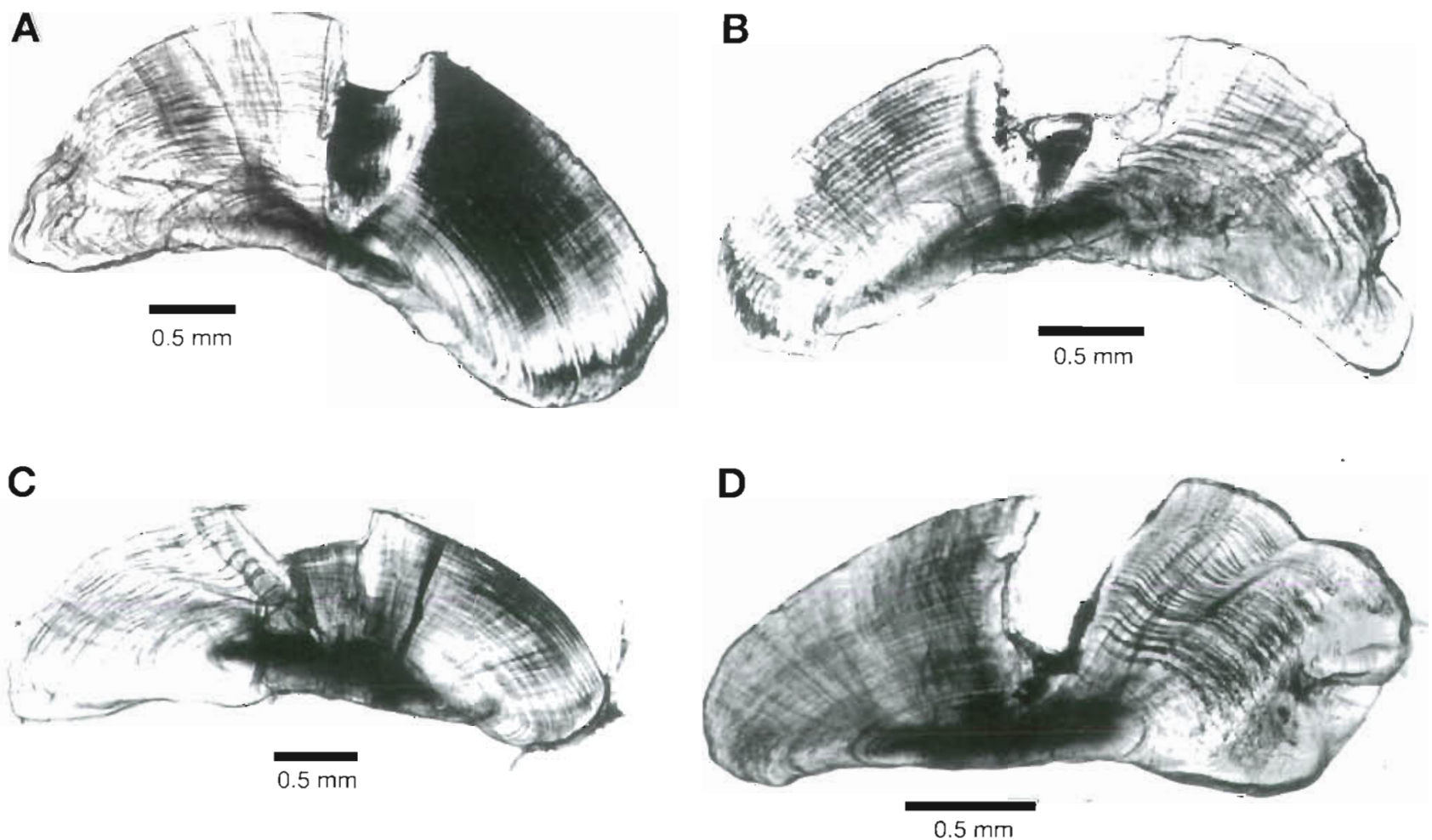

Fig. 2. Sectioned sagittae of acanthurids showing increments. SL: standard length. (A) Acanthurus lineatus: 193 mm SL, North Reef Lizard Island; (B) A. olvvaceus: $186 \mathrm{~mm}$ SL., North Reef Lizard Island; (C) Ctenochaetus striatus: $141 \mathrm{~mm}$ SL, North Reef Lizard Island; (D) Zebrasoma scopas: $134 \mathrm{~mm}$ SL, Osprey Island Lizard Island 
Table 3 . Average percentage errors calculated from 3 independent readings of each otolith in 9 species of acanthurid. For the 5 species of Naso, otolith counts were partitioned into samples in which all individuals were counted

\begin{tabular}{|c|c|c|}
\hline Species & $\mathrm{n}$ & Percentage error \\
\hline Acanthurus lineatus & 78 & 5.5 \\
\hline A. olivaceus & 58 & 5.3 \\
\hline Ctenochaetus striatus & 100 & 6.7 \\
\hline Zebrasoma scopas & 31 & 5.9 \\
\hline Naso brevirostris & 109 & 14.6 \\
\hline Naso brevirostris " & 37 & 5.6 \\
\hline N. hexacanthus & 51 & 8.4 \\
\hline N. hexacanthus ${ }^{\mathrm{a}}$ & 32 & 4.6 \\
\hline N. tuberosus & 45 & 7.0 \\
\hline N. tuberosus & 40 & 6.1 \\
\hline N. unicornis & 44 & 15.8 \\
\hline N. unicornis ${ }^{\tilde{a}}$ & 16 & 5.1 \\
\hline N. vlamingii & 74 & 7.2 \\
\hline N. vlamingii ${ }^{a}$ & 29 & 8.1 \\
\hline
\end{tabular}

a period of greater than 11 mo. The distribution of individuals amongst the 4 study species and the percentage return rates from tagging was Acanthurus olivaceus: 4, 19\%; A. lineatus: 6, 13.3\%; Zebrasoma scopas: $18,38.2 \%$; and Ctenochaetus striatus: 27 , $18.8 \%$. The mean percentage return rate for the whole tagging pool was $21.5 \%$, which reflects the sedentary nature of the species selected. A. lineatus, which has

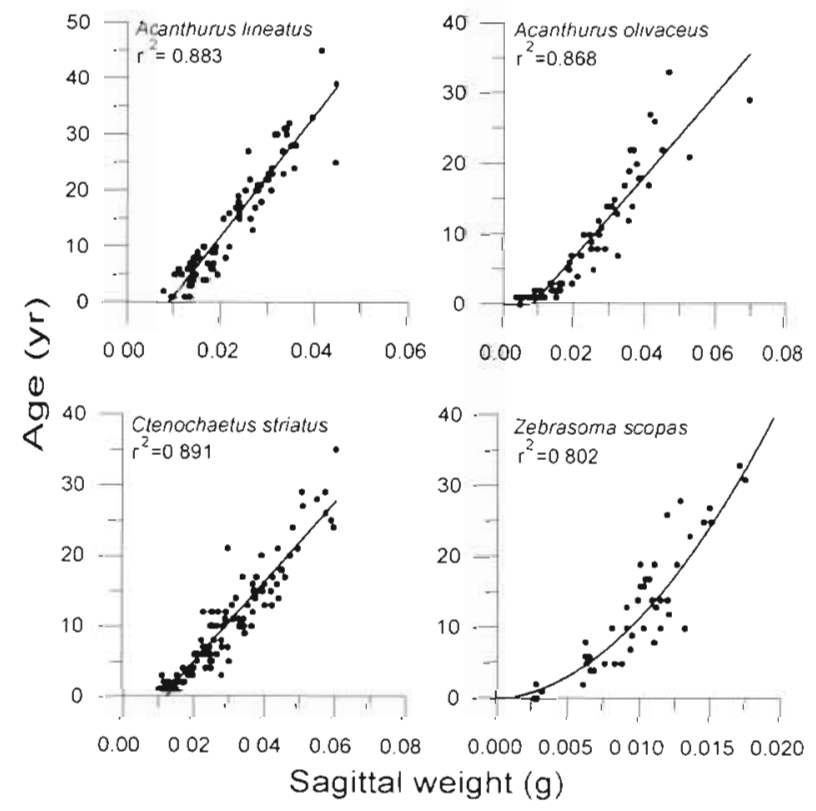

Fig. 3. Least-squares regressions of sagittal increments (age) on sagittal weight. Acanthurus lineatus: $y=-10.07+$ 1077.79x, $\mathrm{n}=80 ;$ A. olivaceus: $y=-5.12+580.88 x, \mathrm{n}=57$; Ctenochaetus striatus: $y=-7.03+571.01 x, \mathrm{n}=120$; Zebrasoma scopas: $\log y=11.11+1.89 \log x, n=43$ deciduous scales, appeared to suffer the greatest posttagging mortality. The mean time at liberty in months for each species was A. olivaceus, 11.7; A. lineatus, $14.3 ; Z$. scopas, $16.4 ;$ and $C$. striatus, 11.6. A number of $Z$ scopas were collected after periods of 21 to 36 mo at liberty. This species was more sedentary and appeared to retain tags longer than other acanthurids.

Some individuals of Ctenochaetus striatus and Acanthurus lineatus were recovered with only the tag base present. As these sedentary species were tagged over a single month-long period, time at liberty could be established. Fifty-four of the tagged individuals were recaptured within $25 \mathrm{~m}$ of the original tagging site. The exception was a single $A$. ollvaceus recovered $350 \mathrm{~m}$ from the tagging site. Not all recovered individuals showed a resolvable tetracycline band under fluorescent light. In $5 \mathrm{C}$ striatus, $8 \mathrm{Z}$. scopas, $2 \mathrm{~A}$. lineatus, and $1 A$. olivaceus the band was either too faint or absent. The remaining recaptures all showed clear tetracycline bands (Fig. 4).

The majority of returns showing successful tetracycline injections had been tagged in November. Representatives of the 4 species showed clear tetracycline bands directly associated with an opaque band (Fig. 5). In each case the opaque band was followed by a larger translucent band. Our interpretation is that opaque bands are laid down in early summer, a view that is consistent with the sagittal patterns seen in other reef fishes (Fowler 1990, 1995, Ferreira \& Russ 1994). Fishes tagged in November 1991 and collected in November 1992 showed a tetracycline band associated with an opaque band and a translucent zone extending to the sagittal margin (Fig. 5). Over the $11.5 \mathrm{mo}$ period between tagging and recapture a single opaque and translucent band was present. There was some difficulty in determining the status of bands at the outer margin of the sagitta.

A number of tagged fish were collected after being at liberty for periods greater than 12 mo. A small individual of Ctenochaetus striatus tagged in February 1992 showed a tetracycline mark at the outer edge of an opaque band. This individual was collected in November 1993 and showed a single opaque and 2 translucent bands. This was a small individual that had shown a relatively large growth increment. A further individual of C. striatus tagged in November 1991 and collected in October 1992 showed a single translucent band. However, this individual had been previously tetracycline-injected in November 1989 during a pilot study program. The October 1992 record was the second recapture. For the period November 1989 to November 1991, 2 translucent and 2 opaque bands were recorded. For the period November 1989 to October 1992, there were 2 opaque and 3 translucent bands (Fig. 5). An individual of $Z$. scopas tagged in November 

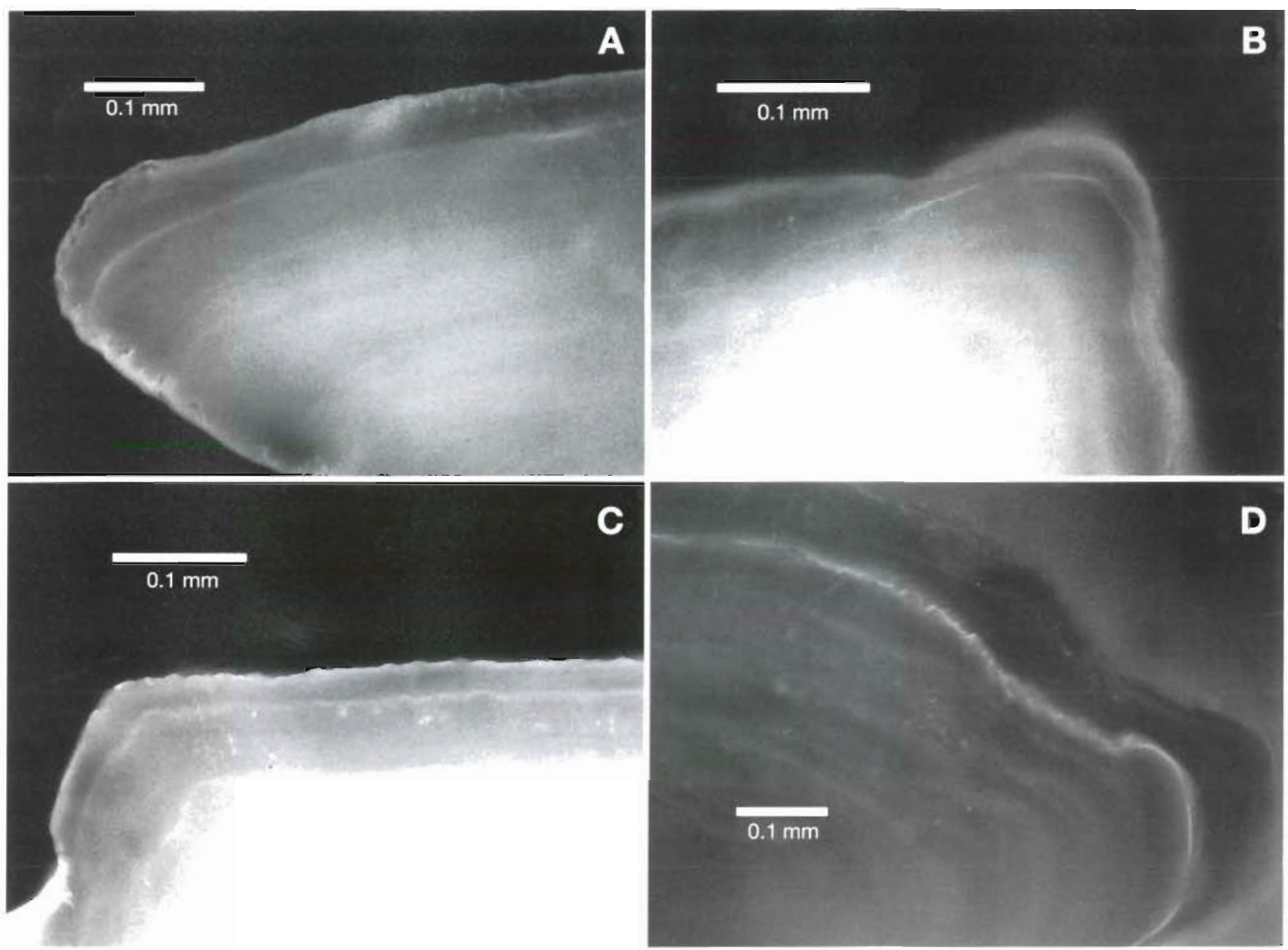

Fig. 4. Sectioned saçittae of ac anthurids recovered after successful tretracycline treatment. (A) Acanthurus lineatus: 179 mm SL, North Reef Lizard Island; (B) A. olivaceus: $201 \mathrm{~mm} \mathrm{SL}$. North Reef Lizard Island; (C) Ctenochaetus striatus: $177 \mathrm{~mm}$ SL, Granite Bluffs, double injected; (D) Zebrasoma scopas: $136 \mathrm{~mm} \mathrm{SL}$, North Reef Lizard Island

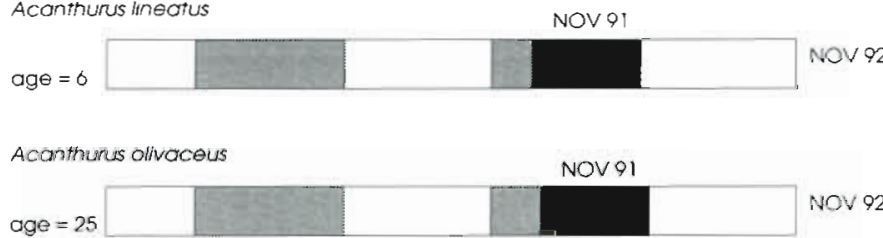

Ctenochoetus striatus

age $=3$\begin{tabular}{|l|l|l|l|l|l|l|}
\hline & NOV 93 \\
\hline
\end{tabular}

Ctenochaetus striotus

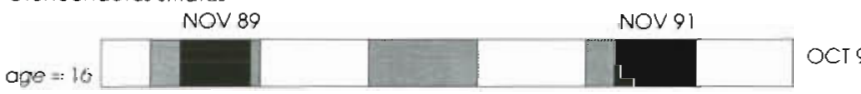

Zebrasomascooas

NOV 91

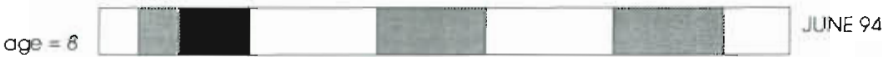

1991 and recaptured June 1994 showed 2 opaque and 3 translucent bands (Fig. 5).

As an additional check on validations, we grew newly settled acanthurids in an outdoor aquarium system for periods greater than 12 mo. These included 1 Acanthurus olivaceus and 2 A. nigricauda, a species which is common at the same locality as the study species. All showed clear annuli which were consistent with the ages of the individuals (Fig. 6).

Fig. 5. Diagrammatic sequence of opaque and translucent increments in the sagittae of 5 acanthurids recovered after tetracycline treatments. Diagrams show relative positions of tetracycline bands, increments and otolith margin. Dates represent time of tagging (top of each bar) and time of collection (end of each bar). Age is an estimate at time of tagging. The fourth example (Ctenochaetus striatus) was double-tagged 


\section{Size at age}

Size at age data plotted for each species revealed consistent and highly characteristic patterns (Fig 7). These showed rapid growth for the first 3 to 4 yr of life in all 4 species. Beyond 4 yr, growth declined sharply, resulting in an extended period over which little change is size occurred. Equations of the general form $\log y=\log a+b \log x$ adequately described the relationship between age and size (Fig 7 ) accounting in general for more than $50 \%$ of the variation in the size/age relationship. Counts of annuli suggested that each of the study species was relatively long-lived. The maximum number of annuli recorded ranged from 32 to 35 in Acanthurus olivaceus, Ctenochaetus striatus and Zebrasoma scopas and up to 46 in A. lineatus. Size is a poor predictor of age in these fishes.

In all species there was evidence of very rapid initial growth especially during the first 2 yr of life. It proved impossible to tag and follow such young individuals in the field. As a check we maintained 1 of the study species, A. olivaceus, in an outdoor aquarium for a period of $16 \mathrm{mo}$. The $30 \mathrm{~mm}$ S.L newly recruited individual grew to $139 \mathrm{~mm}$ SL in $16 \mathrm{mo}$, which was consistent with the length at age plot for this species. The sectioned sagitta displayed 1 annulus (Fig. 6).

The relationship between size at age was variable, especially in Ctenochaetus striatus. Some of the vari-
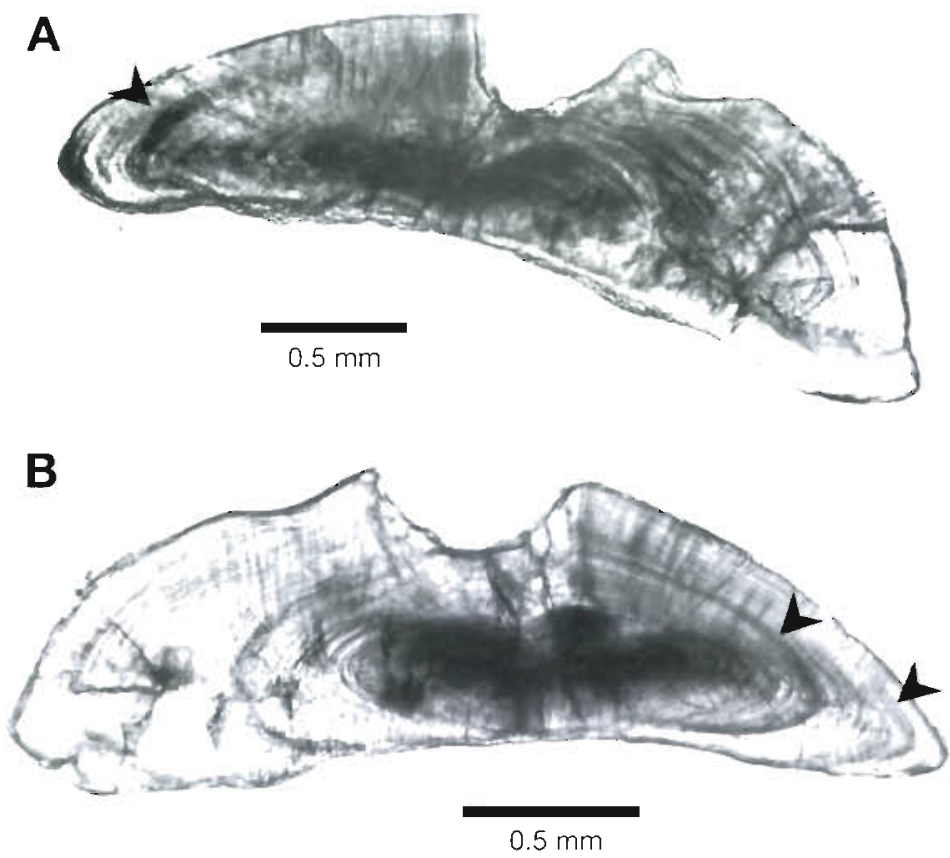

Fig. 6. Sectioned sagittae of 2 species of acanthurid maintained in an outdoor aquarium for periods greater than 12 mo. (A) Acanthurus olivaceus: $16 \mathrm{mo}$; (B) A. nigricauda: $27 \mathrm{mo}$. Arrows show positions of annuli

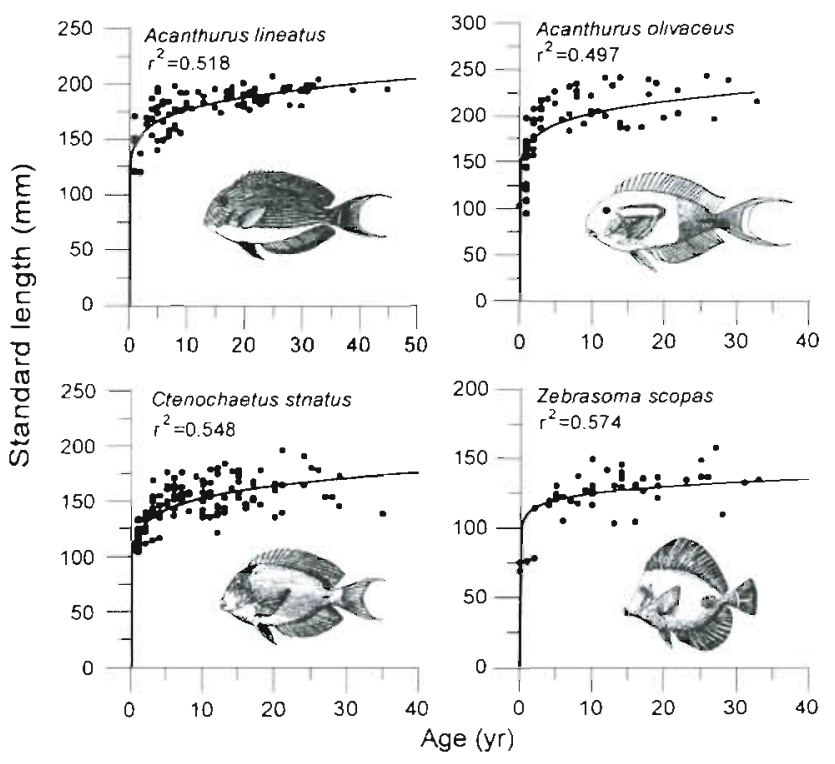

Fig. 7. Size at age relationships for 4 species of acanthurid for which validation of sagittal incrcuients was obtained. The equation $s=a x^{\prime \prime}$ was fitted to each data set

ability was explained by partitioning size at age plots by locality. Most individuals of this species were collected at Lizard Island from adjacent habitats, North Reef and Granite Bluffs (Choat \& Bellwood 1985). Collections from North Reef showed a more variable distribution of ages with size and a lower asymptotic size than those from Granite Bluffs. Specimens from Granite Bluffs had a faster growth rate and achieved a greater size than those from North Reef (Fig. 8A). Comparison of the log-transformed data identified significantly different slopes for the fitted regresssion lines (General Linear Models Procedure; $\mathrm{p}=0.0041)$.

These differences were also reflected in the plot of sagittil weight and age (Fig 8B). In the older age classes the faster growing individuals from Granite Bluffs showed heavier sagitta for a given age. Comparison of the regression lines in Fig. $8 \mathrm{~B}$ identified significant differences between the slopes (General Linear Models Procedure; $p<$ $0.0001)$. Local differences in growth rate and otolith/somatic relationships may be a consistent feature of this detritus feeding acanthurid.

\section{Otolith increments in the genus Naso}

Sectioned sagittae from 5 species, Naso brevirostris, $N$. hexacanthus, $N$. tuberosus, 

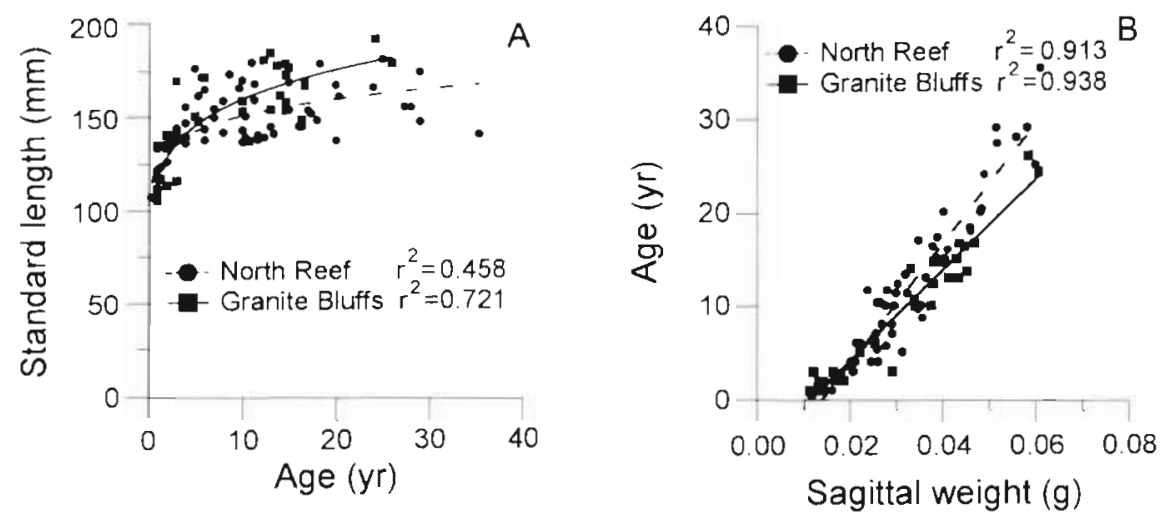

Fig. 8. (A) Locality-specific size at age relationships for Ctenochaetus striatus from North Reef (dashed line) and Granite Bluffs (solid line) Lizard Island. (B) Locality-specific age/sagittal weight relationships for C. striatus from the same localities

A
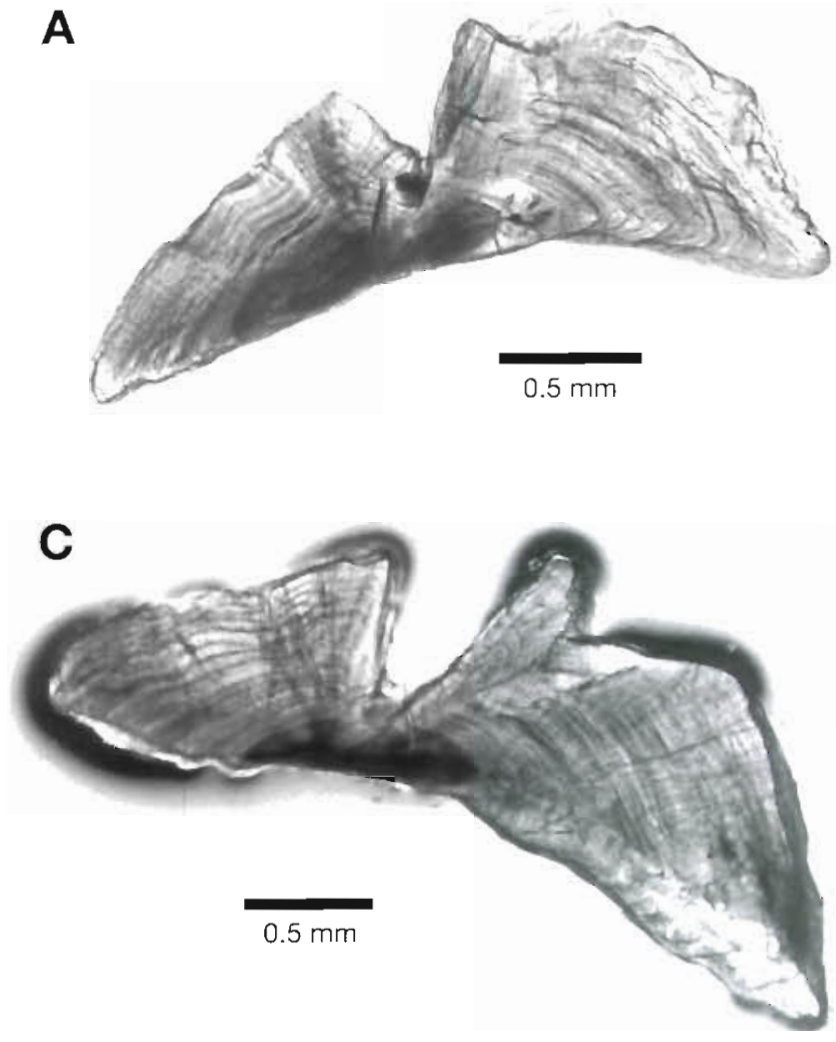

E

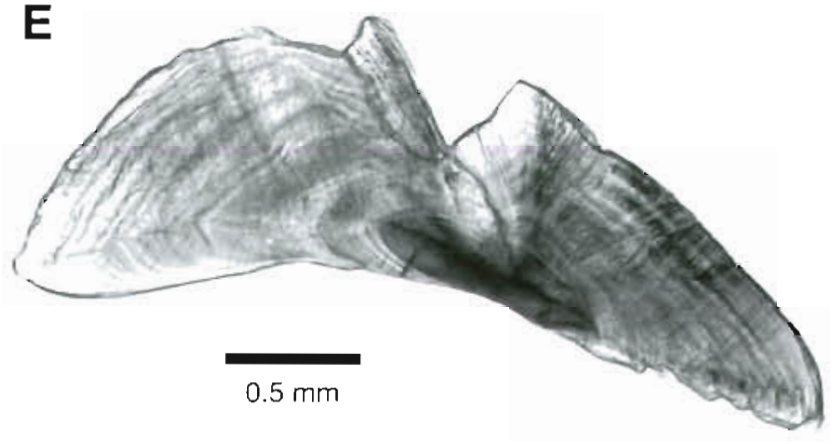

B
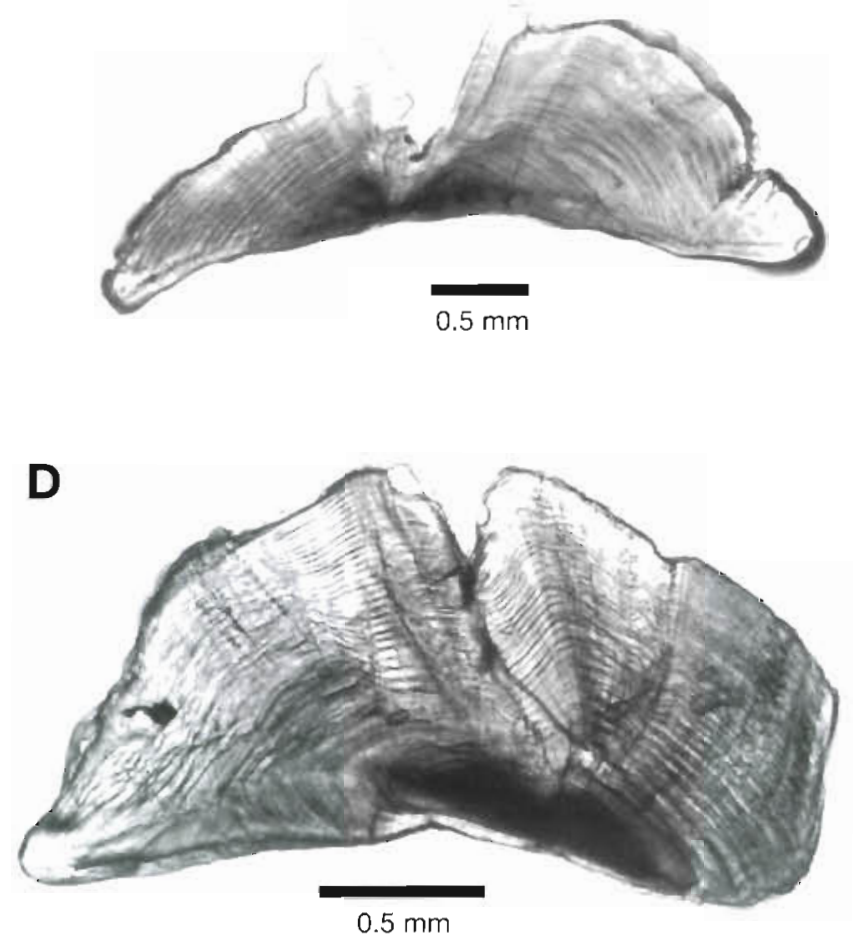

$\mathbf{F}$

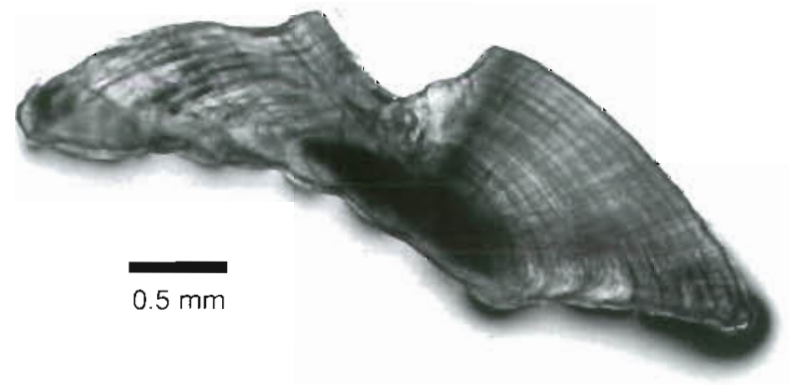

Fig. 9. Sectioned sagittae for 5 Naso species and Prionurus maculatus showing sagittal increments. (A) N. brevirostris: 312 mm $\mathrm{SL}_{i}$ Hicks Reef; (B) N. hexacanthus: $454 \mathrm{~mm}$ SL, Hicks Reef; (C) N. tuberosus: $444 \mathrm{~mm}$ SL, Day Reef (D) N. unicornis: $364 \mathrm{~mm}$ SL, Middleton Reef (E) N. vlamingii: $295 \mathrm{~mm}$ SL, No Name Reef: (F) P. maculatus: $348 \mathrm{~mm}$ SL, Middleton Reef 
$N$. unicornis and $N$. vlamingii, were found to display clear patterns of annuli alternating with translucent zones (Fig 9). Despite a major tagging effort it was not possible to validate the annual nature of these increments. A total of $121 \mathrm{~N}$ brevirostris were tagged and injected on reefs at Lizard Island in February 1992 and a further 57 on Hicks Reef fouter Barrier Reef) in November 1993. Only 2 returns were obtained and none displayed a detectable tetracycline mark in the otolith. There is some possibility that members of this genus do not take up tetracycline at the dosages used.

Sagittal weight showed a strong positive relationship with the number of increments in all species (Fig. 10). This was similar to that seen in species of Acanthurus, Ctenochaetus and Zebrasoma. The relationship between fish length and number of sagittal increments generated patterns similar to the size at age data for Acanthurus, Ctenochaetus and Zebrasoma. However,
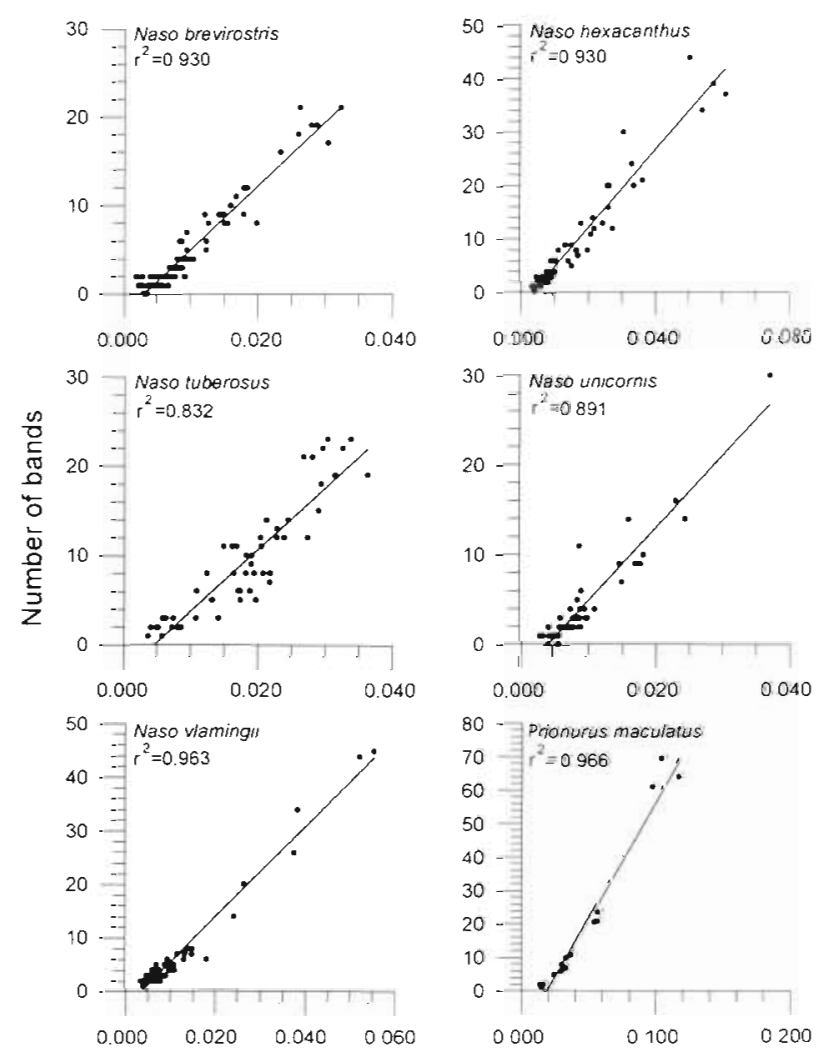

Sagittal weight $(\mathrm{g})$

Fig. 10. Least-squares regressions of sagittal increments (number of bands) on sagittal weights for 5 species of Naso and Prionurus maculatus. (A) N. brevirostns: $y=-2.18+$ $711.09 x, \mathrm{n}=112 ;$ (B) N. hexacanthus: $y=-2.77+721.73 x$. $\mathrm{n}=50 ;$ (C) $N$ tuberosus: $y=-3.23+686.10 x, \mathrm{n}=55 ;$ (D) $N$. unicornis: $y=-3.43+805.14 x, \mathrm{n}=45$; (E) $N$ vlamingii: $y=$ $-3.50+838.78 x, \mathrm{n}=74 ;$ (F) P. maculatus: $y=-14.65+$ $705.99 x, \mathrm{n}=16$ for Naso brevirostris, $N$. hexacanthus, $N$. unicornis and $N$. vlamingii the approach to an asymptotic length was more gradual without the abrupt transition between 2 growth phases. Length continued to increase with increment number. A similar pattern was seen in a small sample of Prionurus maculatus collected from Middleton Reef In $N$. tuberosus the pattern was closer to that seen in the other genera with an abrupt attainment of symptotic growth. Regression equations were fitted to the data. The best fit for $N$. urevirostris, $N$. unicornis and $P$. maculatus was obtained from power curves. For $N$. hexacanthus, $N$. tuberosus and $N$. vlamingii exponential plots gave the best results (Fig. 11). The number of increments suggests that members of the genus Naso attain the same maximum ages as the other acanthurids, in excess of 40 yr for the planktivores $N$. hexacanthus and $N$. vlamingii and in excess of $20 \mathrm{yr}$ for $N$. unicornis, $N$. tuberosus and $N$. brevirostris.
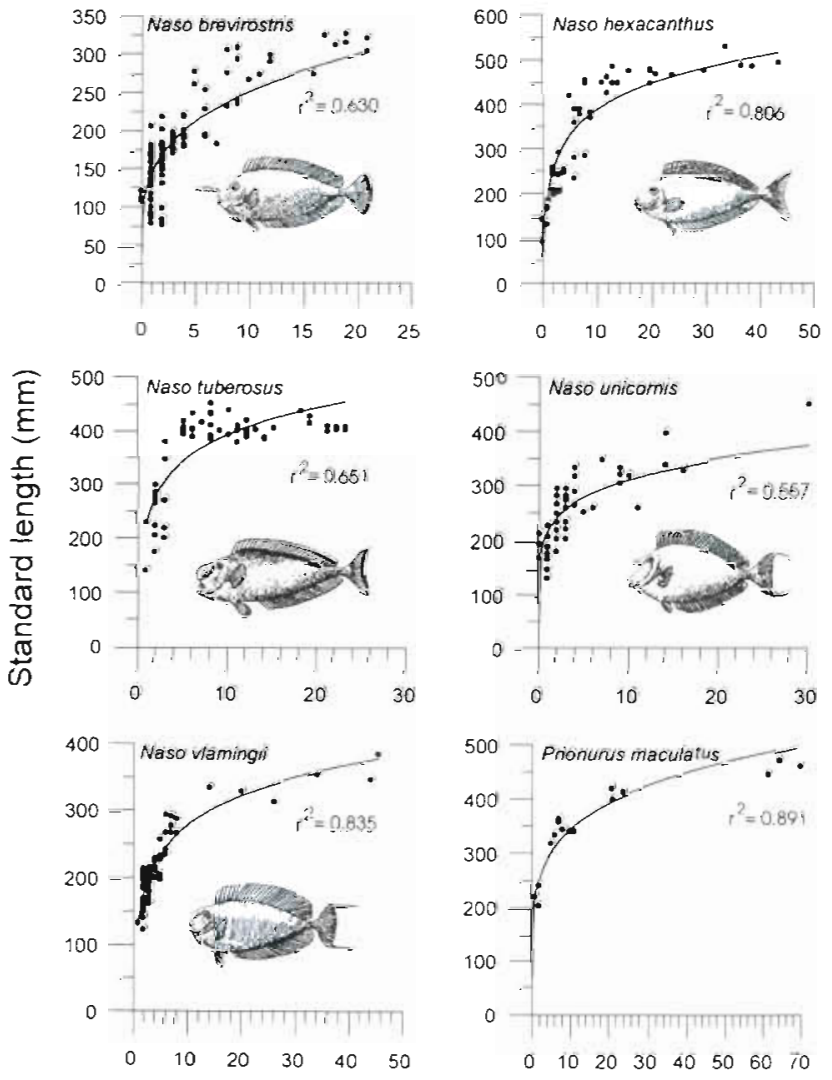

Number of bands

Fig. 11. Relationship between size (SL) and sagittal increments (number of bands) for 5 species of Naso and for Pronurus maculatus. For $N$. brevirostris $(\mathrm{n}=112), N$. unicornis $(n=45)$ and $P$. maculatus $(n=16)$ data are fitted to the equation $y=a x^{b}$ For $N$. hexacanthus $(\mathrm{n}=50), N$. tuberosus $(\mathrm{n}=55)$ and $N$. vlamingii $(n=74)$ data are fitted to $y=a e^{b x}$ 


\section{DISCUSSION}

This study supports the conclusion of Fowler (1995) that many species of coral. reef fishes show clearly defined macroscopic increments in transverse sections of their otoliths, and that when validated the periodicity of increments is annual. These increments are finding increasing use as demographic tools in the study of reef fishes (Doherty \& Fowler 1994, Ferreira \& Russ 1994, Worthington et al. 1995). Our study increases the taxonomic and ecological range of coral reef species for which demographic information may be derived from otolith structure.

A major conclusion from the analysis of acanthurid otoliths was that most species were long-lived, with rapid initial growth which resulted in an asymptotic size being achieved early in life. This pattern is confirmed by independent work on the acanthurid Acanthurus nigrofuscus (Hart \& Russ in press). Consequently, many age classes will accummulate within a relatively narrow size range. In these circumstances the analysis of size frequencies will be of little value as a demographic tool. Similar conclusions have been generated by the study of otoliths of coral-reef associated lutjanids (Newman et al. in press).

The use of otolith increments to estimate growth rates and age structure in tropical reef fishes has encountered 2 types of problems. Firstly the deposition of macroscopic increments may be irregular or may not occur at all (Longhurst \& Pauly 1987). Fowler (1995) suggested that at least for Great Barrier Reef species this will not be a major problem. In some circumstances consistent and discemable increments may occur but the schedule of deposition may not be annual. For example, Milton et al. (1995) argued that increments observed in the sectioned sagittae of some tropical lutjanids may be depositied from 1.6 to 2.4 times per yoar. However, it is unclear what type of environmental signals would drive such an increment pattern. This conclusion was based on radiometric techniques

Examples of radiometric analysis of otoliths in other species of fish have shown that estimates of age from sectioned otoliths and from radiometry are consistent. To date the examples have been from long-lived temperate water fishes (Smith el al. 1995, Stewart et al. 1995). Radiometric assays of long-lived tropical species such as Ctenochaetus striatus for which validation of annuli is available would be informative. Assays of Naso otoliths would also be useful, as it has proved difficult to validate increment formation in this apparently long-lived group. Analysis of the patterns of growth in different otolith dimensions may also provide an insight into life spans and and growth in body size. The results of McFarlane \& Beamish (1995) sug- gested that estimates of growth in otolith thickness would be particularly useful in this context.

In the 4 species in which annual increment formation was validated we were able to estimate the seasonal pattern of deposition of opaque and translucent bands. The deposition of a single opaque band occurred in the early summer which is consistent with most other coral reef fishes (Fowler 1990, 1995, Ferreira \& Russ 1994). Although acanthurids may show a strong annual cycle of reproductive events (Robertson 1983, Fishelson et al. 1987), the deposition of annual rings prior to sexual maturity indicates that this is not the primary stimulus for annulus formation. Acanthurids do show annual cycles of fat deposition and condition (Montgomery \& Galzin 1993), indicating that systematic changes in metabolic activity occur within the year in the tropics

Acanthurids constitute a coherent phylogenetic grouping (Winterbottom 1993, Winterbottom \& McLennan 1993) with Naso the sister group to all other acanthurid genera and Ctenochaetus the most derived member of the generic assemblage. Within this assemblage there is evidence of considerable differentiation with respect to diet and feeding behaviours (Randall 1956, Winterbottom \& McLennan 1993, Clements \& Choat 1995) and in the sizes attained among species (Smith 1966, Jones 1968, Randall et al. 1990). Our findings suggest that despite these differences there is an underlying unity in growth patterns and life spans.

The 10 species examined were all characterised by rapid growth during the first 3 to 5 yr of life. Approximately $80 \%$ of linear growth was accomplished within the initial $15 \%$ of the life span. This pattern was apparent in very small sedentary species, Ctenochaetus striatus and Zebrasoma scopas and suggested in large pelagic planktivores such as Naso hexacanthus. Although there is relatively little information available on acanthurid growth, Randall's studies on Acanthurus triostegus (Randall 1961) confirm our findings of very rapid initial growth.

The highly partitioned nature of age-specific growth in acanthurids has implications for demographic monitoring Recruits would grow through the smaller size stagns very rapidly and merge with the adult population. Monitoring to detect recruitment pulses would need to be designed so that inputs could be identified before this occurred. For adult populations identification of previous recruitment pulses would require analysis of otolith characteristics. The linear relationship between otolith weight and age provides a basis for this (Fletcher 1991), provided the relationship is properly calibrated (Worthington et al. 1995).

The unexpected finding of this study was the distribution of ages in acanthurids. Our estimated longevities suggest that natural mortality rates will be low. Much of the demographic information available to date is 
biased to particular taxa which may be relatively shortlived (Buesa 1987). This will have important implications for for the management of fisheries which include acanthurids and other long-lived species (Russ 1991, DeMartini 1993, Wright 1993). Analysis of otolith structures will have an increasingly important role in the management of reef-based fisheries.

Acknowledgements. The study was supported by an ARC grant to J.H.C. A tagging pilot study was suported by an ARC grant to J.ł.C. and G. R. Russ. Facilities and logistic support were provided by the Lizard Island Research Station and the Australian Museum. Laboratory work and access to aquarium facilites were supported by the James Cook University internal grant system. Assistance with the tagging and sampling program was provided by B. Kerrigan, C. Clements, V. Gleeson, E. Hutchinson, A. Ayling and D. Lou. This work benefitted from discussions with G. Russ, D. Bellwood, P. Craig, C. Clements, A. Hart, J. Higgs and D. Williams. N. Moltschaniwskyj provided assistance and advice with data analysis. Original drawings were done by Lucy Smith.

\section{LITERATURE CITED}

Alcala AC, Russ C.P. (1990) A direct test of the effects of protective management on abundance and yield of tropical marine resources. J Cons Int Explor Mer 46:40-47

Beamish RJ, Fournier DA (1981) A method for comparing the precision of a set of age determinations. Can J Fish Aquat Sci 38:982-983

Buesa RJ (1987) Growth rates of tropical demersal fishes. Mar Ecol Prog Ser 36:191-199

Choat JH (1991) The biology of herbivorous fishes on coral reets. In: Sale PF (ed) The ecology of fishes on coral reefs. Academic Press, San Diego, CA, p 120-1.55

Choat JH, Bellwood DR (1985) Interactions amongst herbivorous fishes on a coral reef: influence of spatial variation. Mar Biol 89:221-234

Choat JH, Bellwood DR (1991) Reef fishes: their history and evolution. In: Sale PF (ed) The ecology of fishes on coral reefs. Academic Press, San Diego, CA., p 39-66

Clements KD, Choat JH (1995) Fermentation in tropical marine herbivorous fish. Physiol Zool 68:355-378

DeMartini EE (1993) Modelling the potential of fishery reserves for managing Pacific coral reef fishes. Fish Bull US 91:414-427

Doherty PJ, Fowler AJ (1994) An empirical test of recruitment limitation in a coral reef fish. Science 263:935-939

Ferreira BP, Russ GR (1992) Age, growth and mortality of the inshore coral trout, Plecropomus maculatus (Pisces: Serranidae) from the Central Great Barrier Reef, Australia. Aust J Mar Freshwat Res 43:1301-1312

Ferreira BP, Russ GR (1994) Age validation and estimation of growth rate of the coral trout, Plectropomus leopardus (Lacepede 1802) from Lizard lsland, Northern Great Barrier Reef. Fish Bull 92:46-57

Fishelson L, Montgomery LW, Myrberg AH Jr (1987) Biology of surgeonfish Acanthurus nigrofuscus with emphasis on changeover in diet and annual gonadal cycles. Mar Ecol Prog Ser 39:37-47

Fletcher WJ (1991) A test of the relationship between otolith weight and age for the pilchurd Sardinops neopilchardus. Can J Fish Aquat Sci 48:35-38

Fowler AJ (1990) Validation of annual growth increments in the otoliths of a small, tropical reef fish. Mar Ecol Prog Ser $64: 25-38$

Fowler AJ (1995) Annulus formation in otoliths of coral reef fish - a review. In: Secor DH, Dean JM, Campana SE (eds) Recent developments in fish otolith research. University of South Carolina Press, Columbia, p 45-63

Hart AM, Russ GR (1996) Response of herbivorous fish to crown of thorns starfish Acanthaster planci outbreaks: age, growth, mortality and maturity indices of Acanthurus nigrofuscus. Mar Ecol Prog Ser (in press)

Jones RS (1968) Ecological relationships in Hawaiian and Johnston Island Acanthuridae (surgeonfishes). Micronesica $4: 309-361$

Longhurst AR, Pauly D (1987) Ecology of tropical oceans. Academic Press, San Diego, CA

Lou DC (1992) Validation of annual growth bands on the otolith of tropical parrotfishes (Scarus schlegeli Bleeker). J Fish Biol 41:775-790

Manooch CS, Drennon CL (1987) Age and growth of yellowtail snapper and queen triggerfish collected from the U.S. Virgin Islands and Puerto Rico. Fish Res 6:53-68

McClanahan TR (1994) Kenyan coral reef lagoon fish: effects of fishing, substrate complexity, and sea urchins. Coral Reefs 13:231-241

McFarlane GA, Beamish RJ (1987) Selection of dosages of oxytetracycline for age validation studies. Can J Fish Aquat Sci 44:905-909

McFarlane GA, Beamish RJ (1995) Validation of the otolith cross section method of age determination for sablefish (Anoplopoma fimbria) using oxytetracycline. In: Secor $\mathrm{DH}$, Dean JM, Campana SE (eds) Recent developments in fish otolith research. University of South Carolina Press, Columbia, p $319-329$

Milton DA, Short SA, O'Nell MF, Blaber SJM (1995) Ageing of three species of tropical snapper (Lutjanidae) from the Gulf of Carpentaria, Australla, using radiometric and otolith ring counts. Fish Bull 93:103-115

Montgomery WL, Galzin R (1993) Seasonality in gonads, fat deposits and condition of tropical surgeonfishes (Teleostei: Acanthuridae). Mar Biol 115:529-536

Munro JL, Williams DMcB (1985) Assessment and management of coral reef fisheries: biological, environmental and socio-economic aspects. Proc 5th Int Coral Reef Congr Tahiti 4:545-581

Newman SJ, Williams DMcB, Russ GR (in press) Age validation, growth and mortality rates of the tropical snappers (Pisces: Lutjanidae), Lutjanus adetii (Castel.nau, 1873) and L. quinquelineatus (Bloch, 1790) from the central Great Barrier Reef, Australia. Mar Freshwat Res $47(4)$

Randall JE (1956) A revision of the surgeon fish genus Acanthurus. Pacif Sci 10:159-235

Randall JE (1961) A contribution to the biology of the convict surgeonfish of the Hawaiian Islands Acanthurus triostegus sandvicensis. Pacif Sci 15:215-272

Randall JE, Allen GR, Steene RC (1990) Fishes of the Great Barrier Reef and Coral Sea. Crawford House Press, Bathurst, Australia

Robertson DR (1982) Fish faeces as fish food on a Pacıfic coral reef. Mar Ecol Prog Ser 7:253-265

Robertson DR (1983) On the spawning behaviour and spawning cycles of eight surgeonfishes (Acanthuridae) from the Indo-Pacific. Environ Biol Fish 9:193-223

Robertson DR, Gaines SD (1986) Interference competition structures habitat use in a local assemblage of coral reef surgeonfish. Ecology 67:1372-1383

Robertson DR, Polunin NVC, Leighton K (1979) The behavioural ecology of three Indian Ocean surgeon fishes 
(Acanthurus lineatus, A. leucosternon, and Zebrasoma scopas) their feeding strategies, and social and mating systems. Environ Biol Fish 4:125-170

Russ GR (1984a) Distribution and abundance of herbivorous grazing fishes in the Central Great Barrier Reef. I. Levels of variability across the entire continental shelf. Mar Ecol Prog Ser 20:23-34

Russ GR (1984b) Distribution and abundance of herbivorous grazing fishes in the Central Great Barrer Reef II. Patterns of zonation of mid-shelf and outer-shelf reefs. Mar Ecol Prog Ser 20:35-44

Russ GR (1991) Coral reef fisheries: effects and yields. In: Sale PF (ed) The ecology of fishes on coral reefs. Academic Press, San Diego, CA, p 601-635

Smith DC. Fenton GE, Robertson SG. Short SA (1995) Age determination and growth of the orange roughy (Hoplostethus atlanticus): a comparison of annulus counts with radiometric ageing. Can J Fish Aquat Sci 52:391-401

Smith JLB (1966) Fishes of a sub-family Nasinae with a synopsis of the Prionurinae. Ichthyol Bull Rhodes Univ 32: $635-682$

Stewart BD. Fenton GE, Smith DC, Short SA (1995) Validation

This article was presented by G. F. Humphrey (Senior Editorial Advisor), Sydney, Australia of otolith-increment age estimates for a deepwater fish species, the warty oreo Allocyttus verrucosus, by radiometric analysis. Mar Biol 123:29-38

Williams DMCB (1991) Patterns and processes in the distroution of coral reef fishes. In: Sale PF (ed) The ecology of fishes on coral reefs. Academic Press, San Diego, CA. p $437-474$

Winterbottom R (1993) Mycological evidence for the phy. logeny of recent genera of surgeonfishes (Percomorpha, Acanthuridae) with comments on the Acanthurioidei Copera 1993:21-39

Winterbottom R, McLinnan DA (1993) Cladogram versatility: evolution and biogeography of acanthuroid fishes. Evolution $47: 1557-1571$

Worthington DG, Doherty PJ, Fowler AJ (1995) Variation in the relationship between otolith weight and age: implications for the estimation of age of two tropical damselfish (Pomacentrus moluccensis and $P$. wardi). Can J Fish Aquat Sci 52:233-242

Wright A (1993) Shallow water reef-associated finfish. In: Wright A, Hill L (eds) Nearshore marine resources of the South Pacific. IPS, Suva, Fiji, p 203-284

Manuscript first received: June 19, 1995

Revised version accepted: November 16, 1995 